NBER WORKING PAPER SERIES

\title{
TO BORROW OR NOT TO BORROW? AN ANALYSIS OF UNIVERSITY LEVERAGE DECISIONS
}

\author{
Harvey S. Rosen \\ Alexander J. W. Sappington \\ Working Paper 21951 \\ http://www.nber.org/papers/w21951
NATIONAL BUREAU OF ECONOMIC RESEARCH
1050 Massachusetts Avenue
Cambridge, MA 02138
January 2016

We are grateful to Princeton's Griswold Center for Economic Policy Studies for financial support of this research. The views expressed herein are those of the authors and do not necessarily reflect the views of the National Bureau of Economic Research.

NBER working papers are circulated for discussion and comment purposes. They have not been peerreviewed or been subject to the review by the NBER Board of Directors that accompanies official NBER publications.

(C) 2016 by Harvey S. Rosen and Alexander J. W. Sappington. All rights reserved. Short sections of text, not to exceed two paragraphs, may be quoted without explicit permission provided that full credit, including (O) notice, is given to the source. 
To Borrow or Not to Borrow? An Analysis of University Leverage Decisions

Harvey S. Rosen and Alexander J. W. Sappington

NBER Working Paper No. 21951

January 2016

JEL No. I22

\begin{abstract}
$\underline{\text { ABSTRACT }}$
This paper investigates the decisions of universities to issue debt. We test whether the expected value and uncertainty of a university's nonfinancial income (the income generated by sources other than its endowment) affect its leverage (the ratio of the value of an institution's liabilities to the value of its assets). We find that leverage is negatively related to both the expected value and the uncertainty of nonfinancial income. On average, increasing the expected value of nonfinancial income by one standard deviation decreases a university's debt by about $\$ 5.1$ million, while increasing the uncertainty of nonfinancial income by one standard deviation decreases debt by about $\$ 2.7$ million. This behavior is consistent with the pecking order theory of capital structure, which posits that managers deplete available internal funds before issuing debt. We also show that the leverage decisions of universities have become less sensitive to expected nonfinancial income but more sensitive to its uncertainty since the Great Recession.
\end{abstract}

Harvey S. Rosen

Department of Economics

Fisher Hall

Princeton University

Princeton, NJ 08544-1021

and NBER

HSR@princeton.edu

Alexander J. W. Sappington

4545 SW 97th Terrace

Gainesville, FL 32608

alexandersappington@gmail.com 


\section{$\underline{\text { Introduction }}$}

According to Moody’s rating agency, university debt levels doubled from 2000 to 2011 (Martin 2012). As the amount of debt issued by universities has grown, so too have concerns about their borrowing practices. The Moody's study, for example, argues that the "Law of More," the collective movement by universities to build lavish facilities in order to attract students, has driven this trend. Indeed, several commentators have suggested that some schools have been borrowing so much that "bond investors have grown wary of their debt” (Korn and Kuriloff 2015). A Forbes article finds fault with debt for another reason, arguing that it is detrimental to the mission of higher education, as public schools with higher debt levels are forced to raise tuition and to admit a greater percentage of wealthy, out-of-state students (Freedman 2014).

Not all the commentary on increased debt has been negative, however. The University of Chicago borrowed nearly \$3 billion between 2002 and 2013, but one municipal fund manager saw nothing particularly wrong with it: "It’s an environment where debt is relatively cheap for [the university] to issue, so I'm not sure it's that much of a negative ... I don’t find it too alarming” (McDonald and Chappatta 2014). In this light, increased debt is simply a rational response to low interest rates.

Before making normative judgments regarding universities' use of debt, it is important to understand how universities decide whether and how much to borrow. Despite concerns about universities’ borrowing practices, the determinants of the debt decisions of universities are largely unexplored in the literature on the financing of higher education. ${ }^{1}$ This paper aims to fill that void.

1 For an exception, see Hansmann (1990) who discusses universities' use of debt in the context of their tax-exempt status. Additionally, Bowman (2002), Denison (2009), and Calabrese (2011) analyze capital 
We view the problem through the lens of the rich literature on the capital structure of for-profit enterprises. Two approaches dominate this literature - the static trade-off and the pecking order theories. We argue that, with suitable modifications, the two theories can be applied to universities, and that they generate empirically testable predictions about how the expected value and uncertainty of a university's nonfinancial income (i.e., income from sources other than the university's endowment, including tuition, government funding, and private donations) affect its demand for debt. We use panel data on a sample of 3,703 universities from 2003 to 2013 to test these models. Because our data extend through 2013, we are able to examine whether the experience of the Great Recession has affected universities’ approach to taking on debt.

Section 2 provides background information comparing the financial decisions of universities with those of for-profit corporations, a discussion of the leading theories of capital structure, and a review of the pertinent empirical literature. In Section 3, we describe the data and present summary statistics. Section 4 details the empirical methodology, including how the expectation and uncertainty of university nonfinancial income are calculated. Section 5 presents and discusses the findings. Our main results are as follows: (1) Leverage - the ratio of total debt to total assets - is negatively related to both the expected value and uncertainty of nonfinancial income. A one standard deviation increase in expected income decreases the debt of a university with the average asset value by $\$ 5.1$ million. A one standard deviation increase in the uncertainty of nonfinancial income decreases debt by $\$ 2.7$ million. These findings are consistent with the pecking order theory of capital structure. (2) Since the Great Recession, university

structure for nonprofit organizations in general, and their datasets include some observations on universities. 
leverage decisions have become less sensitive to expectations of nonfinancial income but more sensitive to uncertainty in these income flows. This is consistent with the notion that universities have become more concerned with the possibility of financial distress. (3) The leverage choices of public and private universities respond similarly to changes in the expected value of nonfinancial income and its uncertainty. (4) Universities with relatively small endowments are more sensitive than universities with larger endowments to both the expected value and uncertainty of nonfinancial income. (5) All of these findings are robust to the inclusion of various controls that have been included in previous analyses of nonprofit leverage decisions. We conclude in Section 6 with a summary and suggestions for future research.

\section{Background and Literature Review}

\subsection{Corporate versus University Finance ${ }^{2}$}

The term "capital structure" refers to an organization's set of financing methods. Three major sources of capital are available to for-profit firms: equity, debt, and retained earnings. Because the theoretical literature on capital structure was originally developed for corporations, we discuss the key differences between universities and for-profit firms as they relate to each of these three sources of capital. ${ }^{3}$

Equity. Perhaps the most salient difference between universities’ and corporations' capital structures is that universities do not use equity at all, simply because they cannot issue stock. Unlike corporations, universities do not have

2 See Bowman (2002) for a more in-depth discussion of the differences in the finances of for-profit and nonprofit organizations.

3 Although for-profit universities do exist, we omit them from our analysis because their capital structure decisions likely differ substantially from nonprofit universities. When we refer to "universities" as a group, we are referring only to public and private not-for-profit universities. 
shareholders (owners). The individuals responsible for operating the university (for example, entering into contracts and even dissolving the university, activities performed by private owners in for-profit firms) are its trustees. Since universities are not privately owned, there is no way to sell partial ownership of the university in the form of equity. Debt. The main difference between universities and corporations with respect to debt arises from the fact that universities enjoy tax-exempt status. That is, universities (1) do not have to pay corporate income taxes ${ }^{4}$ or taxes on the returns to their investments and (2) can issue tax-exempt debt. Because lenders to universities do not have to pay taxes on the interest they receive, universities can borrow at lower rates than taxable entities. ${ }^{5}$ Tax-exempt debt combined with the ability to generate tax-free returns on resources stored in endowments creates the possibility of tax arbitrage - that is, borrowing at low interest rates instead of paying for projects with available funds in order to invest those funds at higher interest rates. ${ }^{6}$ These considerations suggest that universities would tend to take on more debt than for-profit firms, other things being the same. However, one important benefit of corporate debt is less applicable to nonprofits. Interest payments on debt are tax deductible, so debt service reduces corporate income taxes, creating a "tax shield" for for-profit firms. Since universities do not pay tax on the majority of their income, by definition, a tax shield is not much of a benefit for them.

4 Even if an organization is considered tax-exempt, it still has to pay taxes on its unrelated business income. This is income received from a trade or business that is "not substantially related to the charitable, educational, or other purpose that is the basis of the organization's exemption" (Internal Revenue Service, 2015).

5 The law regarding the use of tax-exempt debt has varied over the years. Prior to 1986, all nonprofit (IRC code 501(c)(3)) organizations, including universities, could sell an unlimited amount of taxexempt bonds. In 1986, Congress placed a \$150 million cap on outstanding non-hospital tax-exempt bonds, but repealed this limitation in 1997. Because this study only covers years since 2003, tax-exempt financing is not limited at any time in the analysis sample.

6 Gentry (2002) explores this type of tax arbitrage in a sample of nonprofit hospitals. 
Retained earnings. A corporation's profit is the difference between its revenues and expenses. Profits can be distributed to shareholders as dividends or added to retained earnings. Because universities do not have owners, the terms "profit" and "retained earnings” are not meaningful. However, nonprofit organizations do generate substantial amounts of money from their operations and investments. The difference is that, in order to be legally considered a nonprofit entity and to attain tax-exempt status, nonprofits must abide by a "nondistribution constraint" which mandates that this income stay within the organization as a source of financing. In effect, from this standpoint, a nonprofit organization functions like a for-profit firm that reinvests all of its profits into the business.

We define several terms to avoid confusion when it comes to distinguishing between for-profit firms and universities. First, available funds are a university's stock of accumulated resources from positive net income in prior years. Available funds can be used to fund new projects or pay off debt. In this sense, available funds are analogous to retained earnings for corporations. Second, because there is no analogue to a university endowment in the corporate world, we distinguish between income generated by the investment of endowment assets and income generated by all other university operations. The latter is referred to as nonfinancial income. Finally, the "profitability" of a corporation is often defined as its net operating income divided by the value of its assets. ${ }^{7}$ We call a similar measure for universities normalized nonfinancial income, which is the university's nonfinancial income for a given year divided by its assets at the beginning of that year.

7 See, for example, Titman and Wessels (1988) and Rajan and Zingales (1995). 
External support. There is an additional difference between universities and forprofit firms that may affect capital structure. Although universities cannot access the equity markets, they do have a source of income that is generally unavailable to for-profit firms - funds from federal, state, or local governments, or from private donors. Such support constitutes an average of 44 percent of nonfinancial income in our sample of universities. $^{8}$

\subsection{Theories of Capital Structure}

The two leading theories of capital structure are the static trade-off theory and the pecking order theory. The static tradeoff theory posits that a firm's leverage decision is determined by optimally trading off the costs and benefits of debt finance, while the pecking order theory argues that firms always prefer to use internal funding rather than debt or equity. Empirical tests of the two theories have yielded mixed results so neither one has gained universal acceptance. ${ }^{9}$

Because of the aforementioned institutional differences between corporations and universities, much of this literature deals with issues not relevant to the capital structure decision for universities (or, more generally, nonprofit organizations). ${ }^{10}$ Thus, it is helpful to reinterpret the two theories in the nonprofit context.

8 Some authors (e.g., Wedig (1994)) draw parallels between donors and stockholders, in that both provide capital to an organization and both wield the power to influence certain decisions of an organization's executives and managers. However, unlike stockholders, donors to nonprofits do not have a legal claim to the financial return to their contributions.

9 See Harris and Raviv (1991) for a survey of the theoretical literature on corporate capital structure, and Parsons and Titman (2008) for a more recent overview of the empirical capital structure literature.

10 For example, universities do not have to consider how their leverage should be affected by corporate income taxes (Graham 1996) or by equity market timing (Leary and Roberts 2005). 


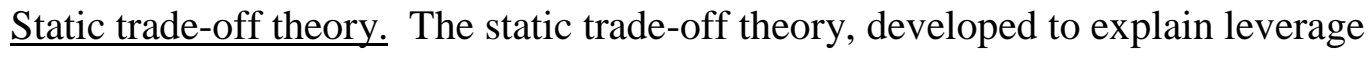
decisions for for-profit corporations, ${ }^{11}$ suggests that managers choose an optimal level of leverage by weighing the costs and benefits of debt. According to this approach, debt has a number of benefits: It allows an organization to pursue investment opportunities beyond what is feasible using retained earnings and cash flow; it can serve to reduce the firm's tax liability (because interest is deductible in the computation of taxable income); and it can attenuate agency problems (Jensen 1986). However, as debt increases, so too does the probability of financial distress. Borrowing generally imposes fixed, rigid payment schedules. If a firm experiences a pronounced reduction in revenues, it may not have enough funds to make debt payments. Furthermore, to the extent that lenders believe that the risk of default rises with the amount of debt, the more debt that the business incurs, the higher the interest rate it must pay. The optimal level of debt, then, balances off these advantages and disadvantages.

As Bowman (2002) and Calabrese (2011) point out, managers of nonprofit organizations confront the same tradeoffs when it comes to the use of debt. Even the tax shield benefit carries over, albeit to a lesser extent, because interest payments can be used to reduce the tax on unrelated business income (Denison 2009). Hence, the predictions about leverage decisions generated by the static tradeoff theory apply to nonprofits, including universities, as well.

Pecking order theory. The pecking order theory says that businesses finance projects with internal funds before taking on debt, and with debt before issuing equity. ${ }^{12}$ The reason is that informational asymmetries between the firm and investors regarding

11 See Kraus and Litzenberger (1973) for the classic exposition of this theory.

12 See Myers and Majluf (1984). Klein et al. (2002) provide a review of this literature. 
the firm's prospects lead investors to undervalue its debt and equity. The hypothesis states that the relatively high costs of debt and equity dominate any potential benefits so that a firm uses all of its retained earnings before seeking funds from the bond or equity markets.

Analogously, in this view a nonprofit organization prefers to finance new projects internally with available funds, and issue debt only if it depletes its supply of available funds. Bowman (2002) suggests another reason why nonprofits might want to avoid debt, reputational concerns. A potential cost of debt for the managers of any organization is the possibility that financial distress will tarnish their reputations or the reputations of their organizations. Bowman argues that such reputational concerns are particularly important for nonprofit organizations because of their reliance on funds from the government and/or private benefactors. These donors might see financial distress as a sign of mismanagement and consequently reduce future contributions.

It follows that to the extent elevated income levels in a given year generate more available funds, the organization's demand for debt falls, other things being the same. Furthermore, just as in the static trade-off model, the greater the financial risk of an organization, the more averse it will be to using debt (Bowman 2002).

\subsection{Empirical Tests of Capital Structure}

The two theories suggest several empirical predictions regarding the determinants of leverage, as described by Fama and French (2002) in the for-profit context and Bowman (2002) and Calabrese (2011) in the nonprofit context. Importantly, the theories have opposite predictions with respect to the impact of expected nonfinancial income on leverage, ceteris paribus. The static trade-off hypothesis implies a positive relationship 
between normalized nonfinancial income and leverage. To the extent that a higher cash flow reduces the likelihood of financial distress, lenders will be willing to accept lower interest rates, reinforcing this positive effect. The pecking order hypothesis, in contrast, implies that leverage will decline as nonfinancial income increases, other things being the same. Given that the organization wants to use available funds before debt whenever possible, increased income (leading to more available funds) reduces the demand for debt.

On the other hand, both theories have the same prediction when it comes to the relationship between leverage and the uncertainty of a nonprofit's income flows. Increased uncertainty leads to a higher probability of financial distress, which increases the costs of borrowing and leads to decreased leverage, other things being the same.

Studies of the debt decisions of nonprofit organizations have used a variety of proxies for the two key variables, income relative to assets and uncertainty in income flows. Bacon (1992) and Calabrese (2011) represent the former as the percentage change in total assets from the previous year. As pointed out by Bowman (2002), however, while an increase in an organization's assets could reflect an increase in its cash flow, it could just as well reflect increased debt, leading to an endogeneity problem. Bowman instead uses the average value of the ratio of a nonprofit's net income to its assets over a fouryear period. However, this measure is problematic for two reasons. First, net income includes endowment income. If certain variables affect leverage and endowment investment strategies simultaneously, ${ }^{13}$ investment income is endogenous to the leverage

13 One variable that might affect both leverage and endowment strategies is the volatility of endowment income. Dimmock (2012) and Rosen and Sappington (2015) show that the volatility in university income affects the proportion of an endowment invested in alternative assets, which, in turn, affects the 
decision and should be excluded from the regression equation. Second, the four-year average includes the contemporaneous value of income. Borrowing decisions likely are made at the beginning of or throughout the course of a fiscal year, and income information is not fully available until the end of the year. Therefore, a manager deciding how much debt to take on in the coming fiscal year can only observe data from the past and use them to develop expectations about income in the current year. In our empirical analysis, then, we examine how expected normalized nonfinancial income of a university, based only on information from prior years, affects its leverage ratio.

The literature presents an even wider variety of measures for the income uncertainty of a nonprofit organization. Following Chang and Tuckman (1994), several studies, including Yan et al. (2009) and Calabrese (2011), construct a HirschmanHerfindahl Index measure of the diversification of the organization's revenue sources, including government funding, donations, program revenue, and investment income. ${ }^{14}$ These papers argue that revenue diversification is the most controllable component of the uncertainty of an organization's revenues, making the diversification index a sensible proxy for uncertainty.

However, basic portfolio theory suggests that this approach is problematic. The uncertainty of the portfolio of revenue sources depends not only on the proportion of income coming from each source, but also on the variances and covariances of the sources. To address this shortcoming, studies that include a diversification index

size of the endowment (Lerner et al., 2008). At the same time, volatility also affects the leverage decision, as documented by Bowman (2002) and Bacon (1992).

14 The formula for the diversification index is: $D I=\frac{1-\sum_{i=1}^{4} R_{i}^{2}}{0.75}$, where $R_{i}$ is the fraction of total revenue generated by each of the four revenue sources. 
sometimes control for the proportion of revenues from each source. ${ }^{15}$ The idea is that a higher proportion of income coming from government sources and program revenues (such as tuition, in the case of universities) leads to increased leverage, as these sources are relatively stable. In contrast, a high proportion of income from donations, which are more volatile, results in lower leverage. However, any correlation between these variables and leverage is open to alternative interpretations. Bowman (2002), Denison (2009), and Fama and Jensen (1983), for example, argue that suppliers of external funds might want nonprofit managers to be very risk averse regarding the use of debt, so a negative sign on the proportions of income from governmental and private donations might simply indicate that external agents influence the organization’s financial decisions.

Bacon (1992) and Bowman (2002) suggest an alternative proxy for financial uncertainty - the variability in earnings as measured by the standard deviation of net income. ${ }^{16}$ Unlike a revenue diversification index, this measure implicitly takes into account the covariances among income channels, providing a more complete measure of an organization's financial risk.However, as Bowman (2002) observes, a drawback of using the standard deviation is that two very different income processes, one with steady growth year after year and the other with alternating ups and downs, could have the same standard deviation. ${ }^{17}$ The organization with fluctuating income flows would likely be in

15 For example, see Yan et al. (2009) and Calabrese (2011).

16 This parallels the techniques generally used in the for-profit literature. For example, see Bradley et al. (1984) and Kale et al. (1991).

17 This is the case because the standard deviation reflects variation from the mean. Suppose, for example, that income increases steadily each year of six consecutive years. Then income in the first three years will lie below the mean whereas income in the second three years will lie above the mean. A substantial standard deviation could result, even though income growth is entirely predictable in this setting. 
greater danger of financial distress, even though the standard deviation would classify them as equivalent in this respect.

Turning now to the results of previous empirical studies of capital structure for nonprofit organizations, it appears that no consensus has been attained. Much of the early literature focused on hospitals. Wedig et al.'s (1989) study, based on a sample of investor-owned, government, and nonprofit hospitals, provides support for the static trade-off theory. Bacon (1992) also analyzes a sample of nonprofit hospitals but comes to the opposite conclusion, finding strong support for the pecking order theory. More recently, researchers have analyzed datasets that pool different types of nonprofits together, including in their samples hospitals, arts and cultural organizations, human services organizations, and universities. Using the IRS's Statistics of Income data, Bowman (2002) finds evidence in support of the static trade-off theory with a positive coefficient on his expected income variable and a negative coefficient on his uncertainty variable. On the other hand, using data from the National Center for Charitable Statistics to study the same wide range of organizations, Calabrese (2011) argues for the pecking order theory on the basis of a finding that expected income has a negative coefficient in a model of leverage decisions. Unlike earlier papers, Calabrese's specification includes organization fixed effects.

The fact that different data sources (coupled with relatively minor methodological differences) produce very different conclusions is discouraging, and suggests that pooling together institutions from the entire nonprofit sector may not be the best approach. After all, different types of nonprofits might have different objectives and constraints, and hence exhibit different financial behaviors. This is one reason why we focus on the 
higher education sector. Further, even with a sample consisting of only a single type of nonprofit, care should be taken to allow for some heterogeneity with respect to capital structure decisions. Hence, our empirical work explicitly allows leverage decisions to vary by type of university.

\section{Data}

Our data come from the Integrated Postsecondary Education Data System (IPEDS), which provides a variety of information on a large set of colleges and universities in the United States. It contains institutional characteristics (such as whether the school is public or private and the highest degree offered) and financial data, including detailed information on revenues, expenditures, endowments, liabilities and assets.

Although IPEDS has been collecting information from higher education institutions continuously since 1987, university accounting practices have changed over the years, and this has changed the information collected by IPEDS. In particular, comparable values of two variables that are important in this paper, total assets and total liabilities, are available for both private and public universities only since 2003. Our analysis sample therefore begins in that year, and extends to $2013 .^{18}$ These data are more recent than those used in previous studies, and allow us to examine how the financial crisis and Great Recession of 2008-2009 impacted debt use.

Unlike assets and liabilities, revenues and expenditures have been reported on a consistent basis since 1987. This is helpful because, as explained below, we construct the

18 Private not-for-profit institutions adopted FASB in 1997, and public institutions adopted GASB in 2003. See Goldstein and Menditto (2005) for an overview of these accounting systems. 
expected value and uncertainty of nonfinancial income using autoregressions estimated with up to six years of data. If income data began only in 2003, we would lose observations from 2003-2009 for the estimation of these autoregressions. Instead, we are able to use income data prior to 2003 to construct observations for 2003-2009, allowing for a longer panel.

The exact number of institutions in the dataset varies from year to year as new schools are created or as schools cease to exist. However, this figure is quite stable over time. In the 2010 fiscal year, the dataset included 1,750 public institutions, 1,855 private not-for-profit institutions, and 2,668 private for-profit institutions. We exclude for-profit schools from the analysis because as discussed above, for-profit organizations face different considerations when making leverage decisions. Thus, when we refer to "private institution” below, we mean only private not-for-profit schools.

To avoid undue influence by outliers, we drop observations that have a value of leverage, expected nonfinancial income, or uncertainty (measured in a fashion described below) in the top or bottom one percent of their respective distributions. ${ }^{19}$ This leaves a sample of 34,309 observations over 3,703 institutions from the years 2003-2013. Summary statistics for the analysis sample are provided in Table 1 . The first panel in the table reports the proportion of public universities in the sample and the proportion of schools offering each of the four primary types of degrees (doctoral, master’s, bachelor's, and associate’s). Previous research shows that these characteristics are significant correlates of financial behavior (Lerner et al., 2008).

19 Since the construction of these variables involves ratios, some observations with numbers close to zero in the denominator can become unreasonably large. Also, in a few cases, an institution's nonfinancial income increased or decreased by extraordinary amounts in a short period of time. The Chronicle of Higher Education (2013) reports large private gifts that, in some cases, generated increases in nonfinancial income of more than 1000 percent in a single year. 
The second panel in Table 1 presents total nonfinancial income and the proportions derived from each of its primary components: government support, private donations, and tuition. On average, universities receive 85 percent of nonfinancial income from these three sources; the remaining 15 percent is derived from sources such as auxiliary enterprises, hospital revenues, and independent operations. The large difference between the mean (\$127 million) and the median (\$37 million) values of nonfinancial income reflects the well-documented fact that resources across universities are highly unequal (Desrochers and Wellman 2011).

Finally, the third panel in Table 1 presents balance sheet data. Leverage is displayed first and then followed by its numerator and denominator, total liabilities and total assets. ${ }^{20}$ Endowment value, which has been shown to be an important correlate of the leverage decision (Bowman (2002)), is presented last. Summary statistics mask considerable variation in these variables over time. Figure 1 shows how the average values of both total liabilities and leverage change over the sample period. Even when adjusted for inflation, the average amount of university debt has risen steadily since 2003 (only declining slightly in 2011). The graph of average leverage, which incorporates movements in total asset value as well as liabilities, tells a somewhat different story.

20 The National Center for Education Statistics defines these variables as follows: (1) “Total assets is the sum of the following amounts: cash, cash equivalents and temporary investments; receivables (net of allowance for uncollectible accounts); inventories, prepaid expenses, and deferred charges; amounts held by trustees for construction and debt service; long-term investments; plant, property, and equipment; and other assets." (2) "Total liabilities is the sum the following amounts: accounts payable; deferred revenues and refundable advances; post-retirement and post-employment obligations; other accrued liabilities; annuity and life income obligations and other amounts held for the benefit of others; bonds, notes, and capital leases payable and other long-term debt, including current portion; government grants refundable under student loan programs; and other liabilities.” Further details are provided in FARM, the Financial Accounting and Reporting Manual. 
While leverage increased slightly from 2003-2007, it shot up dramatically in both 2008 and 2009, which reflects a combination of increased debt as well as declining asset values associated with the financial crisis and the Great Recession. Average leverage then declined and appears to have stabilized from 2011-2013, but at a higher level than in the early and mid-2000s. The Great Recession also disrupted the rapid rise in endowment values, as the average endowment value fell dramatically in 2009 but by 2013 had recovered to near pre-crisis levels.

\section{Econometric Strategy}

In this section we construct a model to estimate how the expected value and uncertainty of nonfinancial income affect the leverage decisions of universities. The theoretical considerations discussed above indicate that the expected value of nonfinancial income and its uncertainty play key roles. Given that these two variables are not observable to the econometrician, they must be constructed. This suggests a twostep procedure that is quite common in the field of finance, although it has not been used to study nonprofit organizations' capital structure. First construct the expectation of nonfinancial income and its uncertainty, and then use them as regressors in an equation with leverage as the dependent variable. We now discuss these two steps in turn.

Estimating the expected value and uncertainty of nonfinancial income. Following Vissing-Jorgensen (2002), we decompose nonfinancial income into two components the "permanent" component, which follows a random walk with drift term $\alpha$, and the "transitory" component, which is a shock to permanent income in a given year. The resulting income process can be modeled as follows: 


$$
\ln Y_{i t}=\alpha+\ln Y_{i, t-1}+\beta X_{i}+\varepsilon_{i t} .
$$

$Y_{i t}$ in equation (1) is inflation-adjusted nonfinancial income for university $i$ in year $t, \alpha$ is a parameter to be estimated, $\varepsilon_{i t}$ is a normally distributed and independent error term that represents the transitory component of university income, ${ }^{21} X_{i}$ is a vector of fixed institutional characteristics, consisting of dichotomous variables indicating whether the school is public or private and its degree-granting status (doctoral, master's, bachelor's, or associate's), and $\beta$ is the associated parameter vector. The $X_{i}$ variables allow for the possibility that different types of institutions have different income processes. The key qualitative findings are robust to including additional institutional characteristics in $X_{i}$ and to omitting $X_{i}$ entirely. Note that although this specification imposes a coefficient of one on $\ln Y_{i, t-1}$, the results are essentially unchanged when we estimate its value along with the other coefficients.

This model assumes that the only information managers have about the nonfinancial income of a university is the inflation-adjusted value of these flows for all past years. Some debt decisions might be made throughout the year as information on contemporaneous income is collected and expectations are adjusted. However, the timing of the arrival of this information is not available in the data, so we assume managers do not rely upon realizations of current period nonfinancial income when determining the extent of the university's leverage.

We also assume that university managers generate their expectations by looking back at a window of a fixed number of years of income data, which captures the idea that

21 The idea of modeling a shock as the residual in an equation is quite common in the literature and has been used in a variety of contexts. For example, the procedure is employed by Jurado et al. (2015) to study macroeconomic uncertainty, Blinder and Deaton (1985) to study how consumption varies with income, and Attanasio et al. (2015) to study family insurance issues. 
the income realizations of relatively recent years have the greatest impact on the expectations of decision-makers. The selection of a window length involves a tradeoff: a window that is too short will not provide sufficient observations to generate meaningful parameter estimates, whereas a window that is too long will result in estimates based on information that university financial officers likely do not consider very relevant to their current decisions. We choose a window of six years, but our substantive results are robust to the use of other reasonable window lengths. ${ }^{22}$ In short, we estimate equation (1) with data from years $t-6$ to $t-1 .^{23}$

With the parameter estimates of equation (1) in hand, we calculate the expected value of the log of nonfinancial income for each university and each year given the prior year's income and characteristics of the university, and denote this value as $\mathrm{M}_{i t}$. We also compute the residuals (i.e., the difference between the actual value of the log of income and its expectation) in each year for each university and calculate the variance of these residuals (denoted $v_{i t}$ ) over the six years used to estimate the model. It can be shown ${ }^{24}$ that the expected value of nonfinancial income is:

$$
e^{\mathrm{M}_{i t}+\frac{v_{i t}}{2}}
$$

Following the convention used in analyses of both for-profit and not-for-profit enterprises, we normalize the expected value of income by the institution's assets at the beginning of the period. Hence, our (normalized) measure of the expected value of nonfinancial income, $\mu_{i t}$, is:

22 Specifically, we also used window lengths of 5 years and 7 years, and the substantive results were not affected.

23 With this algorithm, universities with fewer than six years of operating income data are excluded from the analysis, which is why the number of schools reported in the regressions differs from the number included in the IPEDS dataset.

24 See Vissing-Jorgensen (2002) for a derivation. 


$$
\mu_{i t}=\frac{\mathbb{E}\left(Y_{i t}\right)}{\operatorname{Assets}_{i t}}=\left(e^{\mathrm{M}_{i t}+\frac{v_{i t}}{2}}\right) / \operatorname{Asset}_{i t},
$$

where Assets $_{i t}$ is university $i$ 's total assets at the beginning of year $t$.

Our measure of the uncertainty of nonfinancial income is the coefficient of variation, defined as the standard deviation of a random variable divided by its mean. It is a particularly useful measure when one wants to compare the dispersion of some variable across different groups and the mean of the variable varies considerably across the groups. As mentioned above, this is certainly the case for income flows across universities. A Taylor series expansion indicates that, for any random variable $Z$, the square of the coefficient of variation is approximately equal to the variance of the log of $Z$. Therefore, the coefficient of variation of university $i$ 's nonfinancial income in year $t$ is:

$$
C V_{i t}=\sqrt{\operatorname{Var}\left(\ln Y_{i t}\right)}=\sqrt{v_{i t}} \text {. }
$$

The leverage decision. The next step is to incorporate the estimates of normalized expected nonfinancial income and the coefficient of variation into a model of the leverage decision. Such a model should account for the fact that universities may differ in many dimensions, including their objective functions, their tolerance for risk, and the institutional constraints under which they operate. The panel nature of the data allows us to include university fixed effects to control for all such university characteristics that remain constant over time. We also include time effects to account for factors that affect the debt decisions of all universities in a given year, such as stock market performance, government regulations, interest rates, and the macroeconomic environment. The resulting baseline specification for the model of leverage decisions is:

$$
\text { Leverage }_{i t}=\beta_{0}+\beta_{1} \mu_{i t}+\beta_{2} C V_{i t}+\gamma_{t}+\delta_{i}+\omega_{i t}
$$


where Leverage $_{i t}$ is the ratio of total debt to total assets for university $i$ in year $t, \gamma_{t}$ represents the time effects, $\delta_{i}$ represents the university fixed effects, and $\omega_{i t}$ is a random error.

Because the expected nonfinancial income and coefficient of variation variables used in equation (4) are constructed using a first stage regression, the OLS standard errors will not be correct. Furthermore, the standard errors must be clustered to allow for correlated errors within institutions. To deal with this issue, we employ the method of clustered bootstrapping (Efron and Tibshirani 1986).

Other than the two variables of primary interest, $\mu_{i t}$ and $C V_{i t}$, equation (4) has no variables that vary both across time and across universities. Some of the econometric specifications used in previous papers on nonprofit finance have such variables, so it is useful to consider whether they should be included. For example, as discussed above, some models include the sources of nonfinancial income. Another variable that varies across time and universities is the value of the endowment. Its estimated coefficient in a model of leverage could shed additional light on which of the two theories of capital structure is more consistent with the data (Calabrese 2011). To see why, note that universities make a certain percentage of their endowments available for spending in a given year (see Brown et al. (2014)). The sums paid out from the endowment provide a source of revenue that supplements a university's nonfinancial income. Hence, to the extent that the amount paid out from an endowment varies with its size, the impact of endowment size should have the same directional impact as expected nonfinancial income. Thus, an increase in the ratio of the value of the endowment to total assets would 
increase leverage under the static trade-off theory and decrease leverage under the pecking order theory.

The problem is that decisions that affect the size of the endowment (such as asset allocation and endowment payouts) are likely made simultaneously with leverage decisions. Indeed, the sources of nonfinancial income could also be endogenous, because the amount of money that donors (such as governments or alumni) are willing to put up may depend on how much debt the institution has accumulated. ${ }^{25}$ Nevertheless, to allow comparisons with earlier studies, it is of some interest to see how these variables affect leverage, and whether their inclusion affects our results with respect to the coefficients on $\mu_{i t}$ and $C V_{i t}$. Hence, while recognizing that the results must be interpreted with caution, we estimate a variant of equation (4) that is augmented with: (1) the ratio of the value of the endowment to total university assets; and (2) the proportion of nonfinancial income from each of three major sources - tuition, government funding, and private donations. ${ }^{26}$ This leads to the following model:

$$
\begin{aligned}
\text { Leverage }_{i t}= & \beta_{0}+\beta_{1} \mu_{i t}+\beta_{2} C_{i t}+\beta_{3} \text { EndowRatio }_{i t}+\beta_{4} \text { GovtShare }_{i t} \\
& +\beta_{5} \text { DonorShare }_{i t}+\beta_{6} \text { TuitionShare }_{i t}+\gamma_{t}+\delta_{i}+\omega_{i t} .
\end{aligned}
$$

We have discussed the expected signs on the various coefficients in equation (5) earlier. For convenience, they can be summarized as follows:

- $\quad \beta_{1}(+/-)$ : The static trade-off theory predicts a positive sign on expected nonfinancial income, while the pecking order theory predicts a negative sign.

25 An additional independent variable included in several papers is the total asset value of the organization (see Bowman (2002) and Calabrese (2011)). However, because asset values increase with debt by virtue of an accounting identity, this variable is mechanically endogenous, so we do not include it.

26 As noted above, these three sources make up 85 percent of nonfinancial income, on average. A fourth category, consisting of all other nonfinancial income, is omitted to avoid multicollinearity. 
- $\quad \beta_{2}(-)$ : Both the static trade-off and pecking order models predict a negative sign on the uncertainty variable, as both suggest that a more unpredictable stream of nonfinancial income increases the likelihood of financial distress.

- $\quad \beta_{3}(+/-)$ : The static trade-off model predicts a positive sign on the endowment value relative to assets, as schools backed by large endowments may be able to secure debt at lower costs; the pecking order model predicts a negative sign because higher endowment payouts reduce the demand for debt.

- $\beta_{4}, \beta_{5}(-)$ : According to Bowman (2002) and others, the government and private donors look askance at institutions that accumulate large amounts of debt. If so, this would tend to induce university decision makers to reduce leverage, other things being the same.

- $\quad \beta_{6}(0)$ : Incoming students are unlikely to care about the capital structure of a university. ${ }^{27}$

\section{Results}

\subsection{Basic Findings}

We first estimate the baseline specification, equation (4). The results are reported in the first column of Table 2 . The coefficient on $\mu_{i t}$ is negative and statistically significant, indicating that universities take on less debt when the expectation of nonfinancial income relative to assets rises, ceteris paribus. This finding is consistent with the pecking order theory of debt determination. The next entry in the column

27 Note that to the extent revenue volatility varies inversely with the share of revenues from tuition (because tuition payments are relatively stable), this will be taken into account by the coefficient of variation. 
indicates that as $C V_{i t}$ increases, the amount of leverage decreases, which is consistent with both the pecking order and static tradeoff theories. Hence, taken together, the negative coefficients on both expected nonfinancial income and the coefficient of variation provide support for the pecking order theory - universities choose not to take on debt whenever they can use cash from available funds instead. ${ }^{28}$

To assess the quantitative implications of the coefficient estimates, we use the coefficient on $\mu_{i t}$ to simulate the effect of a one standard deviation increase in normalized expected nonfinancial income. ${ }^{29}$ This generates a decrease in the leverage ratio of 0.017 . While this effect appears small, the change in the dollar amount of debt taken on by the university can be quite large. For a university that has the average value of total assets in our sample, a 0.017 decrease in the leverage ratio equates to a reduction in debt of $\$ 5.1$ million.

An analogous exercise using the coefficient on $C V_{i t}$ indicates that a one standard deviation increase in the coefficient of variation results in a decrease in the leverage ratio of 0.0088 . For a university with the average value of total assets, this implies a decrease of \$2.7 million of debt.

The baseline specification implicitly assumes that the incremental effect of a change in the expectation of nonfinancial income does not depend on the level of

28 As noted above, the signs and significance of the coefficients in the baseline model are robust to a number of changes in the specification of the first-stage equation (equation (1)). When we do not enforce the assumption of a random walk, allowing the coefficient on lagged income to differ from one, the coefficient on $\mu_{i t}$ is -0.047 (s.e. $=0.0099$ ) and the coefficient on $C V_{i t}$ is -0.083 (s.e. $=0.0217$ ). When we use a window of 5 years rather than 6 , the coefficient on $\mu_{i t}$ is -0.037 (s.e. $=0.0092$ ) and the coefficient on $C V_{i t}$ is -0.055 (s.e. $=0.0149$ ). When we use a window of 7 years, the coefficient on $\mu_{i t}$ is -0.057 (s.e. $=0.0101$ ) and the coefficient on $C V_{i t}$ is -0.089 (s.e. $=0.0244$ ). When we omit the control vector of institutional characteristics, the coefficient on $\mu_{i t}$ is -0.048 (s.e. $=0.0092$ ) and the coefficient on $C V_{i t}$ is -0.080 (s.e. $=0.0221$ ).

29 For reference, the standard deviation of normalized expected nonfinancial income is 0.36 . The standard deviation of the coefficient of variation is 0.11 . 
uncertainty, and vice versa. Perhaps, however, when expected income rises so that the likelihood of financial distress falls, then the incremental effect of more uncertainty looms less large in the minds of financial administrators. Alternatively, when revenues are highly unpredictable, university managers might be less responsive to changes in expected nonfinancial income because greater fears of financial distress attenuate the effects of an incremental increase in expected nonfinancial income.

To allow for these possibilities, we add to the baseline specification the interaction of the expectation and uncertainty of nonfinancial income, $\mu_{i t} * C V_{i t}$. The results, presented in the second column of Table 2, indicate that the coefficients on expected nonfinancial income and the coefficient of variation remain negative and statistically significant, and the interaction term is positive and significant. Thus, when either $\mu_{i t}$ or $C V_{i t}$ increases, the impact of changes in the other variable on leverage becomes smaller in absolute value, a finding that is consistent with the scenarios described above.

Columns (3) and (4) of the table indicate that the baseline findings are qualitatively unchanged when the model is augmented with several variables that have been used in previous papers. In particular, expected income and uncertainty both remain negatively related to leverage, and their interaction remains positive. The point estimates on $\mu_{i t}$ and $C V_{i t}$ do change, however. Comparing the results in columns (1) and (3), the absolute values of the negative effects of increased expected nonfinancial income and increased uncertainty are greater and smaller, respectively. A one standard deviation increase in $\mu_{i t}$ now results in a decrease in debt of $\$ 10.0$ million, while a one standard deviation increase in $C V_{i t}$ results in a decrease in debt of $\$ 1.4$ million. 
The coefficients of the other variables in the column are also of interest. The sign on the ratio of endowment value to total assets is negative and statistically significant, which is consistent with the pecking order model of leverage. Universities prefer to finance projects using payouts from the endowment as a supplement to nonfinancial income, rather than taking on debt.

Turning now to the percentages of nonfinancial income generated by each of the university's three primary income sources (government funding, private donations, and tuition), previous work has viewed these variables as proxies for the uncertainty of the university's revenues. In our model, however, such uncertainty is explicitly captured by the $C V_{i t}$ variable. The significant, negative coefficients on the shares of revenue from government funding and private donations, then, might be better viewed as reflecting the external pressures that come with collecting money from these sources. As theorized by Bowman (2002), Denison (2009), and Fama and Jensen (1983), both government and private donors prefer to support nonprofit institutions that carry less debt, other things being the same. This notion gains empirical support from Weisbrod et al.'s (2008) finding that donations to universities increase with endowment size, as donors prefer to give their money to institutions that appear fiscally responsible.

Another observation relating to the augmented models in columns (3) and (4) is that an increase in the share of nonfinancial revenue from tuition has no statistically significant effect on leverage. This contrasts with Yan et al. (2009), who find a positive and significant coefficient. They attribute this to the fact that tuition is a relatively stable source of revenue and therefore reduces the risk of increasing debt, other things being the same. Interestingly, when $\mu_{i t}$ and $C V_{i t}$ are removed from the equation, the coefficient on 
the share of revenues from tuition becomes positive and significant; that is, we are able to replicate Yan et al.'s result. This suggests that because the $C V_{i t}$ variable accounts for the stability of nonfinancial income, the share of tuition is left with no additional role to play in the determination of leverage.

As a reminder, while the results in columns (3) and (4) provide a basis for comparisons to previous research, they must be regarding with caution. The regressors that supplement $\mu_{i t}$ and $C V_{i t}$ in the augmented model might be endogenous.

\subsection{Impact of the Great Recession}

The financial crisis and subsequent Great Recession of 2008 affected universities in many respects, including fundraising, hiring, enrollment, and financial aid. ${ }^{30}$ It is therefore of interest to determine if the Great Recession also changed how universities make their leverage decisions, and in particular, if it made them more sensitive to risk. To address this issue, we re-estimate equations (4) and (5) separately for the years prior to 2008 and for the years 2008 and after. ${ }^{31}$ The findings are presented in Table 3. The first two columns report the results when the baseline model is estimated using data from before and after the financial crisis, respectively. The negative coefficient on expected nonfinancial income before the recession is more than twice as large (in absolute value) as its counterpart after the recession. Furthermore, the coefficient on $C V_{i t}$ prior to the recession is not significant, but the corresponding coefficient after the recession is highly significant and twice the size in absolute value. An F-test indicates that the two models

30 See, for example, Turner (2015) on faculty labor markets, Long (2015) on student enrollment, and Bettinger and Williams (2015) on federal and state financial aid.

31 The number of schools in the analysis sample is smaller in the period before the Great Recession than in the period after the Great Recession. This is because some schools did not begin contributing data to the IPEDS survey until the 2000's, so they did not have the requisite 6 prior years of data available until the post-Recession period. 
are statistically different with a $p$-value less than 0.001 . The same general findings hold in the augmented models in columns (3) and (4). While the absolute value of the coefficient on $C V_{i t}$ does not increase as dramatically after the Great Recession in the augmented specification, one can still reject the hypothesis that the before- and afterrecession models are the same.

These results are consistent with two related but distinct phenomena. In the period leading up to the Great Recession, when university endowments were growing rapidly and reliably (so it seemed), universities put a lot of faith in their expectations of future income, and adjusted their leverage substantially along the lines suggested by the pecking order theory. Specifically, the negative sign on expected nonfinancial income implies that universities anticipating high earnings paid off debt and trusted they would receive sufficient revenues to cover new projects. At the same time, though, the relatively small (in absolute value) coefficient on the coefficient of variation indicates that universities were not very risk averse in the sense that they did not respond much to changes in the uncertainty of their nonfinancial income.

In contrast, after the crisis of 2008, schools adjusted their leverage less on the basis of changes in expected nonfinancial income, possibly due to a decreased trust in earnings predictions after the shock of the financial crisis. At the same time, universities became much more sensitive to the uncertainty of their revenues. We conjecture that the deleterious consequences of possible negative shocks to (say) alumni donations and government grants became more salient to endowment managers after the Great Recession when news of struggling universities swept through the country. ${ }^{32}$ This

32 For example, Antioch College nearly had to shut down in 2008 due to financial distress (Lerner, 2008). 
translated into a greater reduction in leverage in response to increases in the uncertainty of nonfinancial income, other things being the same. In this context, it is important to recall that our model includes time effects. Hence, one cannot attribute our findings with respect to the coefficients on $\mu_{i t}$ and $C V_{i t}$ to (say) general credit tightening or any other aspects of the macroeconomic environment that would tend to lead to reductions in debt.

\subsection{Alternative Specifications}

By using the entire sample of universities to estimate the various models, we have implicitly assumed that every type of school responds to the expected value and uncertainty of nonfinancial income in the same way. While the inclusion of university fixed effects allows each individual institution's leverage to vary, it does not allow for the possibility of different responses to changes in $\mu_{i t}$ and $C V_{i t}$. Given that different types of institutions exhibit different spending and budgeting patterns (Lowry 2004), it seems reasonable that decisions about leverage might differ across types of universities as well. To explore this possibility, we estimate equations (4) and (5) separately for various subgroups of the sample.

Public vs. private. The first characteristic is whether the university is public or private. The distinction is potentially interesting because leverage decisions appear to be made quite differently by public and private institutions. While both types of schools benefit from tax-exempt debt, public universities require state government approval to do so, although the degree of state involvement varies across states and depends on the project that the institution is seeking to finance (Kiley 2012). ${ }^{33}$ The reason for relatively strict government oversight of public universities' leverage decisions likely relates to the

33 The university fixed effects in our model account for any unchanging differences in government policies across states that affect leverage decisions. 
close ties between a state university and the state government itself. Some bonds issued by public schools are issued by the state on behalf of the school, so that bond-rating agencies (like Moody’s) include the debt as part of the state’s overall debt. Furthermore, even if debt is issued by a public university without government assistance, some bonds "carry an obligation that means that if the university were to fail, the state would pay off the bonds” (Kiley 2012). A reasonable conjecture is that more limited internal control over leverage decisions would affect how public schools respond to the expected value and uncertainty in nonfinancial income. More specifically, one might predict that because of the higher degree of government concern about their debt behavior, the coefficient on $C V_{i t}$ would be larger in absolute value for public than for private universities.

The results when the basic model is estimated separately for public and private institutions are reported in columns (1) and (2) of Table 4, respectively. A glance at the coefficients on $\mu_{i t}$ and $C V_{i t}$ across the columns suggests that the point estimate on $C V_{i t}$ is larger in absolute value for public than private universities. However, an F-test indicates that the public and private estimates are not statistically discernible from each other $(p=$ .264). For the augmented specification, the models are significantly different, but that difference is driven by the right hand side variables other than $\mu_{i t}$ and $C V_{i t}$. In short, while the difference in the point estimates is intriguing, the conjecture that public and private schools differ systematically in the way they react to changes in the expected value and uncertainty of nonfinancial income is not supported by the data. As an aside, note that both types of universities exhibit behavior consistent with the pecking order theory, indicating that the results in support of this approach in Table 2 are not driven by a single sector. 
Size of endowment. We next examine whether schools with relatively large endowments respond to nonfinancial income differently than schools with smaller endowments. For these purposes, we divide the sample into two groups based on whether the value of their endowment in 2010 was above or below the median of those included in the baseline regression (which was about $\$ 25$ million). Given that the size of the endowment may be endogenous to the leverage decision and stratifying on an endogenous variable can lead to inconsistent estimates, these results must be viewed with caution. Still, it is interesting to see what tendencies emerge.

The results are presented in Table 5. In the baseline specification, the coefficients on the expected value and the coefficient of variation of nonfinancial income have the expected signs for both subsamples, but are substantially larger in absolute value and statistical significance for the smaller endowments. ${ }^{34}$ That is, universities with relatively small endowments are more sensitive to nonfinancial income flows. This is reasonable because the nonfinancial income of a university with a large endowment is likely supplemented with substantial endowment income, making the expectation of nonfinancial income less important in the leverage decision. Furthermore, a given increase in the coefficient of variation puts a university backed by a large endowment in less danger of financial distress than a university with a small endowment. Put another way, universities with substantial endowments can afford to be less sensitive to nonfinancial income streams, leading to smaller (in absolute value) effects of increased uncertainty on leverage decisions.

34 An F-test rejects the hypothesis that the two sets of coefficients are equal $(\mathrm{p}<0.001)$. 
Given the skewness in the distribution of endowments across universities, the above-the-median group includes an enormous range of values, from about \$25 million to Harvard's $\$ 28$ billion. We investigated whether the results from Table 5 continue to hold when the cutoff for classification as a relatively large endowment is higher, so that the set of universities in it is somewhat more homogeneous. When we re-estimated the model with a cutoff of $\$ 100$ million, the point estimates were quite similar to those in Table 5, but the coefficients were estimated imprecisely for the large-endowment sample, presumably because it was substantially smaller than the sample used to estimate the counterpart in Table 5.

\section{Conclusions}

One author has noted, "Understanding the financing decisions made by nonprofits helps us understand not only their capital choices, but also how nonprofits can provide the maximum sustainable provision of goods and services” (Calabrese 2011). This observation is particularly relevant to higher education. Universities face a perennial tradeoff between providing benefits to current stakeholders (students, faculty, administrators, and staff) and preserving the institution's resources for future generations. A university's debt policy is one important component of the solution to this complicated intertemporal choice problem. To our knowledge, this is the first paper to analyze econometrically the determinants of universities' leverage choices. Our analysis focuses on whether either of the leading theories of corporate capital structure can help explain universities' borrowing decisions. The answer hinges on how universities respond to 
changes in the expected value and uncertainty of their nonfinancial income flows (such as tuition, government grants, and alumni donations).

To investigate this issue, we analyze panel data on the leverage decisions of 3,703 public and private not-for-profit universities from the years 2003 to 2013. Our findings support the so-called pecking order theory of capital structure, which posits that universities prefer to finance projects using available funds rather than debt whenever possible. In our preferred specification, a one standard deviation increase in normalized expected nonfinancial income results in a decrease in debt of $\$ 5.1$ million for a university with the average asset value, while a one standard deviation increase in the uncertainty of nonfinancial income (measured by the coefficient of variation) is associated with a \$2.7 million decrease in debt. These findings are robust to the incorporation of various variables that have been included in previous research on nonprofit capital structure.

We also find that the Great Recession seems to have structurally changed how universities' leverage decisions respond to changes in their economic environment. Since the recession, universities' leverage decisions have become more sensitive to the uncertainty associated with nonfinancial income and less sensitive to its expected value. This behavior may have arisen because the financial crisis and ensuing recession made university decision-makers less confident in their projections of nonfinancial income and more aware of how downturns in their revenues can lead to financial distress.

Finally, while there is some heterogeneity across institutions in how leverage decisions are affected by various factors, especially between universities with small and large endowments, the point estimates on the key coefficients consistently lend support to the pecking order theory. Particularly noteworthy is our finding that, despite the 
apparently different institutional structures that govern private and public universities’ financial decision making, they respond similarly to changes in the expected value and uncertainty of nonfinancial income. Thus, our result that universities’ leverage decisions are consistent with the pecking order theory is not driven by any one type of institution. While it would be incautious to use these results to draw any inferences about the determinants of capital structure in for-profit organizations, it is interesting to note that, as Smith (2010) points out, nonprofits are ideally suited for empirically testing theories of capital structure because their financial mechanisms are, in many ways, simpler than those of for-profit firms.

Several issues remain to be explored in future research. For example, our model does not account for the possibility that universities issue debt for purposes of tax arbitrage. ${ }^{35}$ A promising way to explore this issue would be to take advantage of the regulatory changes in the cap on tax-exempt debt enacted in 1986 and 1997, a strategy that was not open to us because our analysis sample begins in 2003. In addition, as time moves on and the Great Recession fades from the minds of university managers, it would be interesting to examine whether the manner in which leverage decisions are made reverts to its pre-2008 mode. .

\footnotetext{
${ }^{35}$ Gentry (2000) has explored this issue in the context of nonprofit hospitals.
} 


\section{$\underline{\text { References }}$}

Attanasio, O., Meghir, C., and Mommaerts, C. (2015). Insurance in Extended Family Networks. National Bureau of Economic Research, Working Paper No. 21059.

Bacon, P.W. (1992). Do Capital Structure Theories Apply to Nonprofit Hospitals? Journal of the Midwest Finance Association, 21, 86-90.

Bettinger, E., and Williams, B. (2015). Federal and State Financial Aid during the Great Recession. In J.R. Brown and C.M. Hoxby, How the Financial Crisis and Great Recession Affected Higher Education (pp. 175-207). Chicago: The University of Chicago Press.

Blinder, A.S. and Deaton, A. (1985). The Time Series Consumption Function Revisited. Brookings Papers on Economic Activity, 0(2), 465-511.

Bowman, W. (2002). The Uniqueness of Nonprofit Finance and the Decision to Borrow. Nonprofit Management and Leadership, 12(3), 293-311.

Bradley, M., Jarrell, G., and Kim, E.H. (1984). On the Existence of an Optimal Capital Structure: Theory and Evidence. Journal of Finance, 39(3), 857-878.

Brown, J., Dimmock, S., Kang, J., and Weisbenner, S. (2014). How University Endowments Respond to Financial Market Shocks: Evidence and Implications. American Economic Review, 104(3), 931-962.

Brown, J.R., Dimmock, S.G., and Weisbenner, S. (2015). The Supply and Demand for Charitable Donations to Higher Education. In J.R. Brown and C.M. Hoxby, How the Financial Crisis and Great Recession Affected Higher Education (pp. 175-207). Chicago: The University of Chicago Press.

Calabrese, T.D. (2011). Testing Competing Capital Structure Theories of Nonprofit Organizations. Public Budgeting \& Finance, 31(3), 119-143.

Carnesale, A. (2006). The Private-Public Gap in Higher Education. The Chronicle of Higher Education, 15(18), B20.

Cejneck, G., Franz, R., Randl, O., and Stoughton, N. (2013). A Survey of University Endowment Management Research. Available at SSRN 2205207.

Chang, Cyril F., and Howard P. Tuckman. 1994. Revenue Diversification Among Nonprofits. Voluntas: International Journal of Voluntary and Nonprofit Organizations, 5(3), 273-290.

Desrochers, D.M. and Wellman, J.V. (2011) Trends in College Spending, 1999-2009, Delta Cost Project, Washington, DC. 
Denison, D.V. (2009). Which Nonprofit Organizations Borrow? Public Budgeting and Finance, 29(3), 110-123.

Dimmock, S.G. (2012). Background Risk and University Endowment Funds. The Review of Economics and Statistics, 94(3), 789-799.

Efron, B. and Tibshirani, R. (1986). Bootstrap Methods for Standard Errors, Confidence Intervals, and Other Measures of Statistical Accuracy. Statistical science, 54-75.

Fama, E.F. and French, K.R. (2002). Testing Trade-Off and Pecking Order Predictions About Dividends and Debt. Review of Financial Studies, 15(1), 1-33.

Fama, E.F. and Jensen, M.C. (1983). Separation of Ownership and Control. Journal of Law and Economics, 26(2), 301-325.

Freedman, J. (2014). “The Hidden College Problem: When Universities, Not Just Students, Take on Debt.” Forbes, March 19. www.forbes.com.

Gentry, W.M. (2002). Debt, Investment, and Endowment Accumulation: the Case of Notfor-Profit Hospitals. Journal of Health Economics, 21, 845-872.

Goldstein, L. and Menditto, S. (2005). “GASB and FASB.” National Association of College and University Business Officers, January. www.nacubo.org.

Graham, J.R. (1996). Debt and the Marginal Tax Rate. Journal of Financial Economics, 41, 41-73.

Hansmann, H. (1990). Why Do Universities Have Endowments? Journal of Legal Studies, 19(3).

Harris, M., and Raviv, A. (1991). The Theory of Capital Structure. Journal of Finance, 46(1), 297-355.

Jensen, M. (1986). Agency Costs of Free Cash Flow, Corporate Finance, and Takeovers. American Economic Review, 76(2), 323-329.

Jurado, K., Ludvigson, S.C., and Ng, S. (2015). Measuring Uncertainty. American Economic Review, 105(3), 1177-1216.

Kale, J.R., Noe, T.H., and Ramirez, G.G. (1991). The Effect of Business Risk on Corporate Capital Structure: Theory and Evidence. Journal of Finance, 46(5), 16931715. 
Kiley, K (2012). “Building With Your Hands Tied.” Inside Higher Ed, April 26. (https://www.insidehighered.com/news/2012/04/26/kentucky-limits-debt-issuancehinder-university-constructions)

Klein, L. S., O’Brien, T. J. and Peters, S. R. (2002). Debt vs. Equity and Asymmetric Information: A Review. Financial Review, 37: 317-349.

Korn, M. and Kuriloff, A., “Problems Mount for the 'Other' College Debt,” The Wall Street Journal, October 8, 2015. (http://www.wsj.com/articles/problems-mount-for-theother-college-debt-1444296600)

Kraus, A., and Litzenberger, R.H. (1973). A State-Preference Model of Optimal Financial Leverage, Journal of Finance, 28(4), 911-922.

Leary, M.T. and Roberts, M.R. (2005). Do firms rebalance their capital structures? Journal of Finance, 60(6), 2575-2619.

Lerner, J., Schoar, A., and Wang, J. (2008). Secrets of the Academy: The Drivers of University Endowment Success. Journal of Economic Perspectives, 22(3), 207-22.

Long, B.T. (2015). The Financial Crisis and College Enrollment: How Have Students and Their Families Responded? In J.R. Brown and C.M. Hoxby, How the Financial Crisis and Great Recession Affected Higher Education (pp. 175-207). Chicago: The University of Chicago Press.

Lowry, R.C. (2004). Markets, Governance, and University Priorities: Evidence on Undergraduate Education and Research. Economics of Governance, 5, 29-51.

Major Private Gifts to Higher Education. Chronicle.com. The Chronicle of Higher Education, 20 October 2013.

Martin, A. (2012). "Degrees of Debt: Building a Showcase Campus, Using an I.O.U.” The New York Times, December 13. www.nytimes.com.

McDonald, M. and Chappatta, B. (2014). "University of Chicago is Outlier with Growing Debt Load.” Bloomberg Business, March 17. www.bloomberg.com.

Miller, M.H., and Modigliani, F. (1961). Dividend Policy, Growth, and the Valuation of Shares. Journal of Business, 34(4), 411-432.

Myers, S.C., and Majluf, N.S. (1984). Corporate Financing and Investment Decisions When Firms Have Information That Investors Do Not Have. Journal of Financial Economics, 13(2), 187-221.

National Center for Education Statistics. 1987-2013. "Integrated Postsecondary Education Data System.” United States Department of Education. 
Parsons, C. and Titman, S. (2008). Empirical Capital Structure: A Review. Foundations and Trends in Finance, 3(1), 1-93.

Publication 598: Tax on Unrelated Business Income of Exempt Organizations. Internal Revenue Service, rev. January 2015. http://www.irs.gov/pub/irs-pdf/p598.pdf (accessed March 24, 2015).

Rajan, R. G. and Zingales, L. (1995). What Do We Know About Capital Structure? Some Evidence from International Data. Journal of Finance, 50(5), 1421-1460.

Rosen, H.S. and Sappington, A.J.W. (2015), What Do University Endowment Managers Worry About? An Analysis of Alternative Asset Investments and Background Income, National Bureau of Economic Research, Working Paper No. 21271.

Smith, G.P. (2010). What are the Capital Structure Determinants for Tax-Exempt Organizations? The Financial Review, 45, 845-872.

Titman, S. and Wessels, R. (1988). The Determinants of Capital Structure. Journal of Finance, 43(1), 1-19.

Turner, S.E. (2015). The Impact of the Financial Crisis on Faculty Labor Markets. In J.R. Brown and C.M. Hoxby, How the Financial Crisis and Great Recession Affected Higher Education (pp. 175-207). Chicago: The University of Chicago Press.

Vissing-Jorgensen, A. (2002). Towards an Explanation of Household Portfolio Choice Heterogeneity: Nonfinancial Income and Participation Cost Structures. National Bureau of Economic Research, Working Paper No. 8884.

Wedig, G.J. (1994). Risk, Leverage, Donations, and Dividends-in-Kind: A Theory of Nonprofit Financial Behavior. International Review of Economics and Statistics, 3(3), 257-278.

Wedig, G.J., Sloan, F.A., Hassan, M., and Morrisey, M.A. (1989). Capital Structure, Ownership, and Capital Payment Policy: The Case of Hospitals. Journal of Finance, 43, 21-40.

Weisbrod, B., Ballou, J., and Asch, E. (2008). Donations and the Pursuit of Mission in Higher Education. Northwestern University Institute for Policy Research Working Paper No. 08-04.

Yan, W., Denison, D.V., and Butler, J.S. (2009). Revenue Structure and Nonprofit Borrowing. Public Finance Review, 37(1), 47-67. 
Table $1^{\dagger}$

\section{Summary Statistics}

\begin{tabular}{|c|c|c|c|c|}
\hline University Characteristics & Proportion & & & \\
\hline Public & $49.8 \%$ & & & \\
\hline Doctoral & $7.8 \%$ & & & \\
\hline Master’s & $17.6 \%$ & & & \\
\hline Bachelor's & $17.9 \%$ & & & \\
\hline Associate’s & $28.4 \%$ & & & \\
\hline Nonfinancial Income & & & & \\
\hline & Mean & $25^{\text {th }}$ percentile & Median & $75^{\text {th }}$ percentile \\
\hline Nonfinancial Income (\$ millions) & 127.1 & 15.9 & 36.9 & 86.8 \\
\hline Reliance on each Source (\%) & & & & \\
\hline Government Support & 33.1 & 2.7 & 36.2 & 57.4 \\
\hline Private Donations & 10.7 & 0.8 & 4.2 & 14.6 \\
\hline Tuition and Fees & 41.6 & 22.0 & 37.6 & 60.4 \\
\hline Balance Sheet Information & Mean & $25^{\text {th }}$ percentile & Median & $75^{\text {th }}$ percentile \\
\hline Leverage (\% of total assets) & 33.3 & 16.1 & 29.8 & 45.5 \\
\hline Total Debt (\$ millions) & 100.4 & 3.9 & 18.5 & 63.5 \\
\hline Total Assets & 301.9 & 22.0 & 65.7 & 182.3 \\
\hline Endowment Value & 128.2 & 2.0 & 10.2 & 43.9 \\
\hline
\end{tabular}

${ }^{\dagger}$ The first panel shows the distribution of universities in the sample by institution type and the four largest categories of degree type. The calculations in this panel are not weighted by the number of observations in the analysis sample. The second panel shows information relating to flows of income from various sources, computed over all observations in the analysis sample. The third panel reports balance sheet data for universities computed across all observations in the analysis sample. All dollar figures are in millions of 2010 dollars; the adjustment is made using the Higher Education Price Index. 
Figure $1^{\dagger}$

(A) Average Inflation-Adjusted Debt from 2003 to 2013

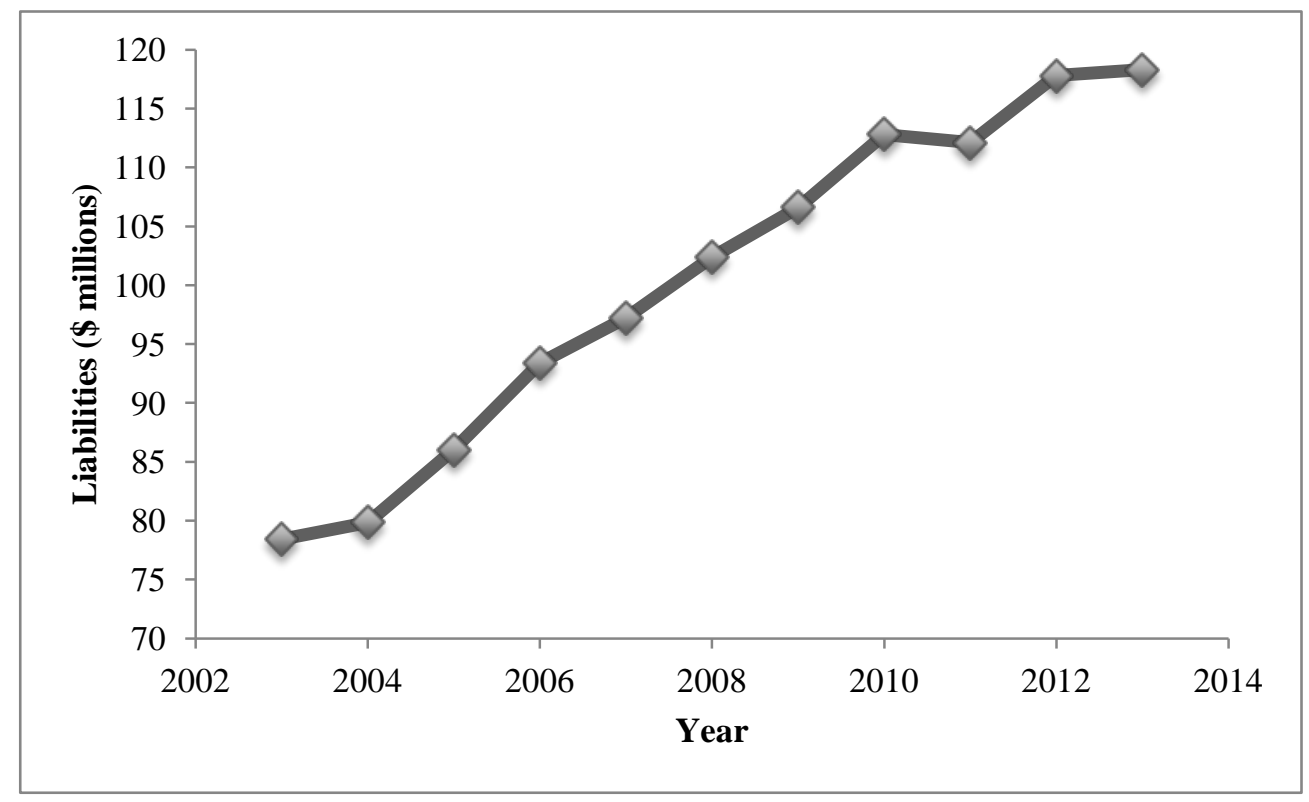

(B) Average Leverage from 2003 to 2013

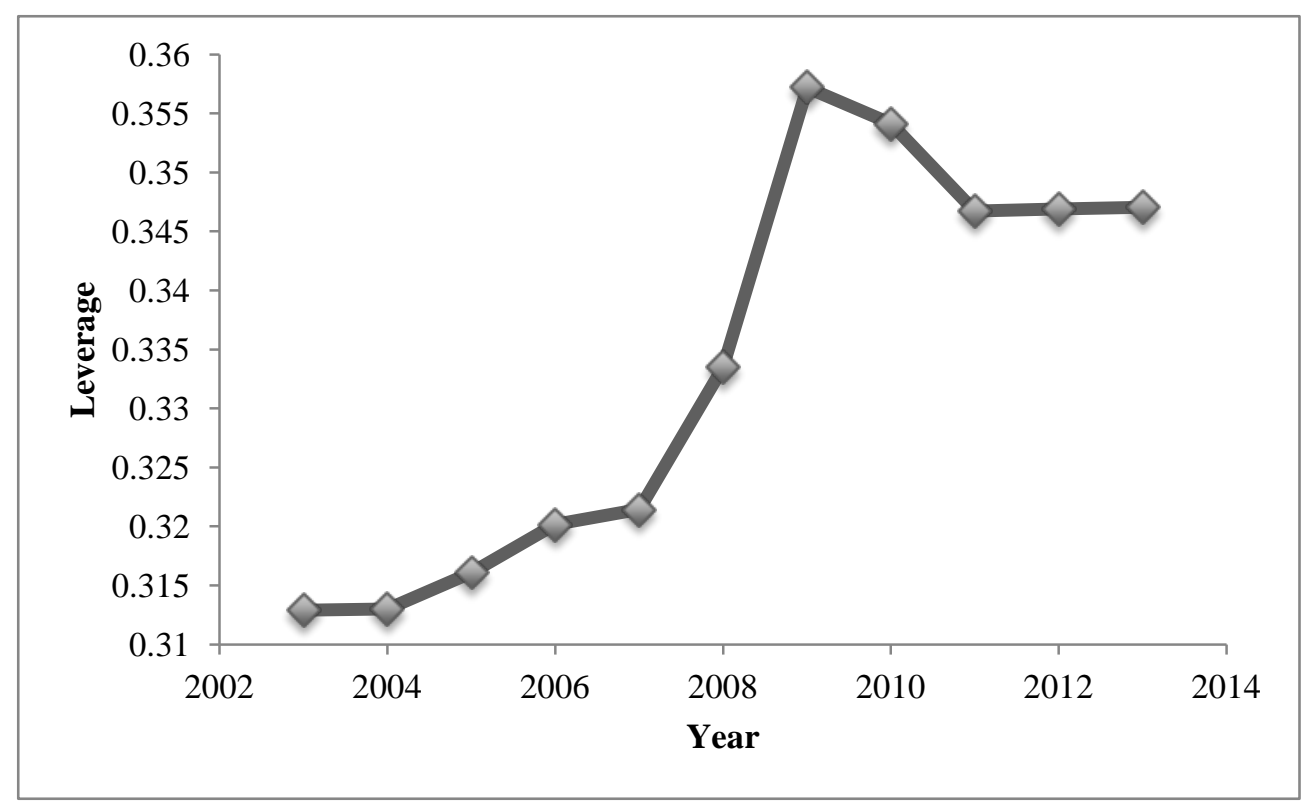

${ }^{\dagger}$ Panel A shows the trends over time in the average value of total liabilities, in millions of 2010 dollars. Panel B shows the trend in average leverage, defined as the ratio of liabilities to assets. The data are obtained from IPEDS. 
Table $2^{\dagger}$

The Leverage Decision for All Universities and Years

\begin{tabular}{|c|c|c|c|c|}
\hline & \multicolumn{2}{|c|}{ Baseline Model } & \multicolumn{2}{|c|}{ Augmented Model } \\
\hline & (1) & (2) & (3) & $(4)$ \\
\hline$\mu_{i t}$ & $\begin{array}{c}-0.0462 * * * \\
(0.0111)\end{array}$ & $\begin{array}{c}-0.0612 * * * \\
(0.0140)\end{array}$ & $\begin{array}{c}-0.0918 * * * \\
(0.0113)\end{array}$ & $\begin{array}{c}-0.108 * * * \\
(0.0147)\end{array}$ \\
\hline$C V_{i t}$ & $\begin{array}{c}-0.0803^{* * *} \\
(0.0211)\end{array}$ & $\begin{array}{c}-0.130 * * * \\
(0.0263)\end{array}$ & $\begin{array}{c}-0.0433^{* *} \\
(0.0187)\end{array}$ & $\begin{array}{c}-0.101 * * * \\
(0.0287)\end{array}$ \\
\hline$\mu_{i t} * C V_{i t}$ & & $\begin{array}{c}0.0861^{* *} \\
(0.0352)\end{array}$ & & $\begin{array}{l}0.118 * * \\
(0.0483)\end{array}$ \\
\hline EndowRatio $_{i t}$ & & & $\begin{array}{c}-0.102^{* * *} \\
(0.0233)\end{array}$ & $\begin{array}{c}-0.101^{* * *} \\
(0.0253)\end{array}$ \\
\hline GovtShare $_{i t}$ & & & $\begin{array}{c}-0.115^{* * *} \\
(0.0244)\end{array}$ & $\begin{array}{c}-0.113^{* * * *} \\
(0.0291)\end{array}$ \\
\hline DonorShare $_{i t}$ & & & $\begin{array}{c}-0.123^{* * *} \\
(0.0219)\end{array}$ & $\begin{array}{c}-0.123 * * * \\
(0.0241)\end{array}$ \\
\hline TuitionShare $_{i t}$ & & & $\begin{array}{c}0.0222 \\
(0.0198)\end{array}$ & $\begin{array}{c}0.0193 \\
(0.0229)\end{array}$ \\
\hline Constant & $\begin{array}{l}0.363 * * * \\
(0.00855)\end{array}$ & $\begin{array}{c}0.372 * * * \\
(0.0105)\end{array}$ & $\begin{array}{c}0.434^{* * *} \\
(0.0153)\end{array}$ & $\begin{array}{c}0.444^{* * *} \\
(0.0203)\end{array}$ \\
\hline University Effects & Yes & Yes & Yes & Yes \\
\hline Year Effects & Yes & Yes & Yes & Yes \\
\hline Observations & 24,896 & 24,896 & 17,939 & 17,939 \\
\hline R-squared & 0.034 & 0.035 & 0.091 & 0.092 \\
\hline Number of Schools & 3,113 & 3,113 & 2,317 & 2,317 \\
\hline
\end{tabular}

${ }^{\dagger}$ This table shows the estimates of the baseline model of the university leverage decision, both without (column 1) and with (column 2) the interaction of the properties of nonfinancial income. The estimates of the model augmented with additional controls are presented in columns 3 and $4 . \mu_{i t}$ is the university's forecast of nonfinancial income normalized by the value of the university's assets, as estimated by equation (2). $C V_{i t}$ is the coefficient of variation of nonfinancial income estimated by equation (3). Clustered and bootstrapped standard errors are in parentheses. Significance levels are indicated by: $* 10 \%$, **5\%, ***1\% level. 
Table $3^{\dagger}$

The Leverage Decision Before and After the Great Recession.

\begin{tabular}{|c|c|c|c|c|}
\hline & \multicolumn{2}{|c|}{ Baseline Model } & \multicolumn{2}{|c|}{ Augmented Model } \\
\hline & $\begin{array}{c}(1) \\
\text { Before Great } \\
\text { Recession }\end{array}$ & $\begin{array}{c}(2) \\
\text { After Great } \\
\text { Recession }\end{array}$ & $\begin{array}{l}\text { (3) } \\
\text { Before Great } \\
\text { Recession }\end{array}$ & $\begin{array}{c}(4) \\
\text { After Great } \\
\text { Recession }\end{array}$ \\
\hline$\mu_{i t}$ & $\begin{array}{c}-0.0878^{* * * *} \\
(0.0152)\end{array}$ & $\begin{array}{c}-0.0413 * * * \\
(0.0126)\end{array}$ & $\begin{array}{c}-0.125^{* * *} \\
(0.0259)\end{array}$ & $\begin{array}{c}-0.0704 * * * \\
(0.0195)\end{array}$ \\
\hline$C V_{i t}$ & $\begin{array}{l}-0.0378 \\
(0.0345)\end{array}$ & $\begin{array}{c}-0.0795 * * * \\
(0.0273)\end{array}$ & $\begin{array}{l}-0.0319 \\
(0.0394)\end{array}$ & $\begin{array}{c}-0.0471^{*} \\
(0.0270)\end{array}$ \\
\hline EndowRatio $_{i t}$ & & & $\begin{array}{c}-0.0371 \\
(0.0246)\end{array}$ & $\begin{array}{c}-0.183^{* * *} \\
(0.0432)\end{array}$ \\
\hline GovtShare $_{i t}$ & & & $\begin{array}{l}-0.0970 * \\
(0.0499)\end{array}$ & $\begin{array}{c}-0.0507^{* *} \\
(0.0206)\end{array}$ \\
\hline DonorShare $_{i t}$ & & & $\begin{array}{c}-0.0924^{* * *} \\
(0.0245)\end{array}$ & $\begin{array}{c}-0.0764^{* * * *} \\
(0.0182)\end{array}$ \\
\hline TuitionShare $_{i t}$ & & & $\begin{array}{c}0.0213 \\
(0.0255)\end{array}$ & $\begin{array}{c}0.0485^{* * *} \\
(0.0168)\end{array}$ \\
\hline Constant & $\begin{array}{c}0.384 * * * \\
(0.0142)\end{array}$ & $\begin{array}{l}0.371^{* * *} \\
(0.00764)\end{array}$ & $\begin{array}{c}0.425 * * * \\
(0.0266)\end{array}$ & $\begin{array}{c}0.418^{* * *} \\
(0.0177)\end{array}$ \\
\hline University Effects & Yes & Yes & Yes & Yes \\
\hline Year Effects & Yes & Yes & Yes & Yes \\
\hline Observations & 8,889 & 16,007 & 6,504 & 11,435 \\
\hline R-squared & 0.037 & 0.024 & 0.072 & 0.079 \\
\hline Number of Schools & 2,044 & 3,018 & 1,462 & 2,247 \\
\hline
\end{tabular}

${ }^{\dagger}$ This table shows the estimates of the baseline model of the university leverage decision estimated separately before the Great Recession (2003 - 2007) in column 1 and after it (2008 - 2013) in column 2. The estimates of the model augmented with additional controls are presented in columns 3 and $4 . \mu_{i t}$ is the university's forecast of nonfinancial income normalized by the value of the university's assets, as estimated by equation (2). $C V_{i t}$ is the coefficient of variation of nonfinancial income estimated by equation (3). Clustered and bootstrapped standard errors are in parentheses. Significance levels are indicated by: $* 10 \%, * * 5 \%, * * * 1 \%$ level. 


\section{Table $4^{\dagger}$}

\section{Public Versus Private Institutions}

\begin{tabular}{|c|c|c|c|c|}
\hline & \multicolumn{2}{|c|}{ Baseline Model } & \multicolumn{2}{|c|}{ Augmented Model } \\
\hline & (1) & (2) & (3) & (4) \\
\hline & Public & Private & Public & Private \\
\hline \multirow{2}{*}{$\mu_{i t}$} & $-0.0592 * * *$ & $-0.0713^{* * *}$ & $-0.0855^{* * *}$ & $-0.0955^{* * *}$ \\
\hline & $(0.0187)$ & $(0.0181)$ & $(0.0211)$ & $(0.0166)$ \\
\hline \multirow[t]{2}{*}{$C V_{i t}$} & $-0.109 *$ & $-0.0790 * * *$ & -0.0727 & $-0.0443 *$ \\
\hline & $(0.0631)$ & $(0.0231)$ & $(0.0518)$ & $(0.0246)$ \\
\hline \multirow{2}{*}{ Endow Ratio $_{i t}$} & & & -0.0163 & $-0.140 * * *$ \\
\hline & & & $(0.0207)$ & $(0.0312)$ \\
\hline \multirow[t]{2}{*}{ GovtShare $_{i t}$} & & & $-0.129 * * *$ & -0.0192 \\
\hline & & & $(0.0377)$ & $(0.0363)$ \\
\hline \multirow[t]{2}{*}{ DonorShare $_{i t}$} & & & $-0.306 * * *$ & $-0.134 * * *$ \\
\hline & & & $(0.113)$ & $(0.0289)$ \\
\hline \multirow{2}{*}{ TuitionShare $_{i t}$} & & & $0.113^{* *}$ & -0.00171 \\
\hline & & & $(0.0537)$ & $(0.0214)$ \\
\hline \multirow[t]{2}{*}{ Constant } & $0.350 * * *$ & $0.365^{* * *}$ & $0.424 * * *$ & $0.447 * * *$ \\
\hline & $(0.0204)$ & $(0.0104)$ & $(0.0334)$ & $(0.0210)$ \\
\hline University Effects & Yes & Yes & Yes & Yes \\
\hline Year Effects & Yes & Yes & Yes & Yes \\
\hline Observations & 9,248 & 14,378 & 6,868 & 11,071 \\
\hline R-squared & 0.065 & 0.043 & 0.099 & 0.106 \\
\hline Number of Schools & 1,347 & 1,450 & 1,129 & 1,191 \\
\hline
\end{tabular}

${ }^{\dagger}$ This table shows the estimates of the baseline model of the university leverage decision estimated separately for public (column 1) and private (column 2) universities. The estimates of the model augmented with additional controls are presented in columns 3 and $4 . \mu_{i t}$ is the university's forecast of nonfinancial income normalized by the value of the university's assets, as estimated by equation (2). $C V_{i t}$ is the coefficient of variation of nonfinancial income estimated by equation (3). Clustered and bootstrapped standard errors are in parentheses. Significance levels are indicated by: ${ }^{*} 10 \%$, **5\%, ***1\% level. 
Table $5^{\dagger}$

\section{Universities Classified by Size of Endowment}

\begin{tabular}{|c|c|c|c|c|}
\hline & \multicolumn{2}{|c|}{ Baseline Model } & \multicolumn{2}{|c|}{ Augmented Model } \\
\hline & $\begin{array}{c}(1) \\
\text { Below Median }\end{array}$ & $\begin{array}{c}(2) \\
\text { Above Median }\end{array}$ & $\begin{array}{c}\text { (3) } \\
\text { Below Median }\end{array}$ & $\begin{array}{c}(4) \\
\text { Above Median }\end{array}$ \\
\hline$\mu_{i t}$ & $\begin{array}{c}-0.0780^{* * *} \\
(0.0151)\end{array}$ & $\begin{array}{c}-0.0235^{*} \\
(0.0127)\end{array}$ & $\begin{array}{c}-0.0949 * * * \\
(0.0152)\end{array}$ & $\begin{array}{c}-0.0843 * * * \\
(0.0309)\end{array}$ \\
\hline$C V_{i t}$ & $\begin{array}{c}-0.143 * * * \\
(0.0339)\end{array}$ & $\begin{array}{c}-0.0271 \\
(0.0196)\end{array}$ & $\begin{array}{c}-0.0807^{* *} \\
(0.0383)\end{array}$ & $\begin{array}{c}-0.0145 \\
(0.0221)\end{array}$ \\
\hline EndowRatio $_{i t}$ & & & $\begin{array}{c}-0.136^{* * *} \\
(0.0292)\end{array}$ & $\begin{array}{c}-0.0833^{* *} \\
(0.0338)\end{array}$ \\
\hline GovtShare $_{i t}$ & & & $\begin{array}{c}-0.126^{* * *} \\
(0.0358)\end{array}$ & $\begin{array}{l}-0.111^{* *} \\
(0.0484)\end{array}$ \\
\hline DonorShare $_{i t}$ & & & $\begin{array}{c}-0.178^{* * *} \\
(0.0303)\end{array}$ & $\begin{array}{c}-0.0677 * * * \\
(0.0236)\end{array}$ \\
\hline TuitionShare $_{i t}$ & & & $\begin{array}{c}0.0371 \\
(0.0233)\end{array}$ & $\begin{array}{c}0.000932 \\
(0.0238)\end{array}$ \\
\hline Constant & $\begin{array}{c}0.399 * * * \\
(0.0148)\end{array}$ & $\begin{array}{c}0.336^{* * *} \\
(0.0112)\end{array}$ & $\begin{array}{c}0.467 * * * \\
(0.0218)\end{array}$ & $\begin{array}{c}0.399 * * * \\
(0.0270)\end{array}$ \\
\hline University Effects & Yes & Yes & Yes & Yes \\
\hline Year Effects & Yes & Yes & Yes & Yes \\
\hline Observations & 13,010 & 11,886 & 10,130 & 7,809 \\
\hline R-squared & 0.045 & 0.031 & 0.088 & 0.117 \\
\hline Number of Schools & 1,564 & 1,549 & 1,450 & 867 \\
\hline
\end{tabular}

${ }^{\dagger}$ This table shows the estimates of the baseline model of the university leverage decision estimated separately for universities in the sample for our baseline regression with endowments below the median value in 2010 (column 1) and above the median (column 2). The estimates of the model augmented with additional controls are presented in columns 3 and $4 . \mu_{i t}$ is the university's forecast of nonfinancial income normalized by the value of the university's assets, as estimated by equation (2). $C V_{i t}$ is the coefficient of variation of nonfinancial income estimated by equation (3). Clustered and bootstrapped standard errors are in parentheses. Significance levels are indicated by: $* 10 \%, * * 5 \%$, $* * * 1 \%$ level. 